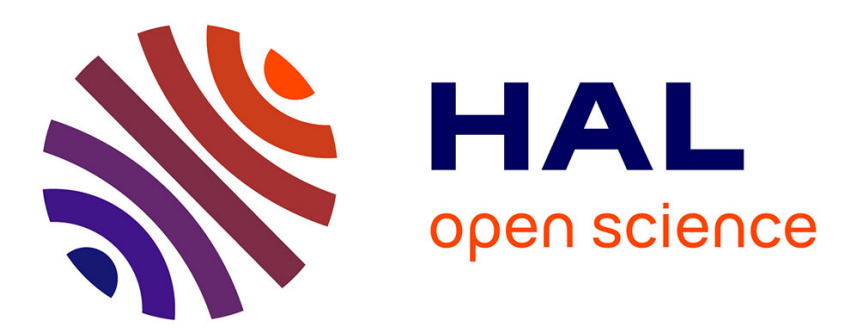

\title{
Evaporite accumulation during the Messinian Salinity Crisis: The Suez Rift case.
}

J. Gargani, Isabelle Moretti, J. Letouzey

\section{To cite this version:}

J. Gargani, Isabelle Moretti, J. Letouzey. Evaporite accumulation during the Messinian Salinity Crisis: The Suez Rift case.. Geophysical Research Letters, 2008, 35 ((2)), pp.L02401.1-L02401.6, doi:10.1029/2007GL032494 (IF 2,959). hal-00357241

\section{HAL Id: hal-00357241 \\ https://hal.science/hal-00357241}

Submitted on 28 Apr 2021

HAL is a multi-disciplinary open access archive for the deposit and dissemination of scientific research documents, whether they are published or not. The documents may come from teaching and research institutions in France or abroad, or from public or private research centers.
L'archive ouverte pluridisciplinaire HAL, est destinée au dépôt et à la diffusion de documents scientifiques de niveau recherche, publiés ou non, émanant des établissements d'enseignement et de recherche français ou étrangers, des laboratoires publics ou privés. 


\title{
Evaporite accumulation during the Messinian Salinity Crisis: The Suez Rift case
}

\author{
Julien Gargani, ${ }^{1,2}$ Isabelle Moretti, ${ }^{1}$ and Jean Letouzey ${ }^{1}$ \\ Received 31 October 2007; revised 30 November 2007; accepted 10 December 2007; published 16 January 2008.
}

[1] The Mediterranean Basin may have not always been connected to the Atlantic Ocean. During the Messinian Salinity Crisis (5.96-5.33 Myr), the Mediterranean Sea reduced progressively its connection with the global Ocean by a complex combination of tectonic and glacio-eustatic processes. During this period, deep erosion occurred on the margin and on the continent. Furthermore, a large quantity of evaporites was deposited in the basins $(>1500 \mathrm{~m})$. The way by which the evaporites accumulated in the various subbasins has not been precisely determined. Here we demonstrate by quantitative analysis that a combination of several Mediterranean sea-level drawdown events associated with limited Atlantic sea inflow and continuous river discharge can explain the quantity of evaporites in the Mediterranean Basins and the observation of an intermediate lowstand at $\sim 500 \mathrm{~m}$. Using a paleogeographical reconstruction and a numerical model, we show that the evaporites of the Gulf of Suez (GoS) are a consequence of the threshold which disconnected the GoS/ Red Sea from the Eastern Mediterranean at the end of the Miocene. Citation: Gargani, J., I. Moretti, and J. Letouzey (2008), Evaporite accumulation during the Messinian Salinity Crisis: The Suez Rift case, Geophys. Res. Lett., 35, L02401, doi:10.1029/2007GL032494.

\section{Introduction}

[2] The Mediterranean Basin reduced significantly its exchange with the Atlantic Ocean during the Messinian (Figure 1). When partly or totally isolated, the Mediterranean water level depends on the hydrological flux and is expected to vary significantly. The sea water restriction and possibly isolation, from the Atlantic Ocean triggered unique conditions of sedimentation. A large quantity of evaporites (>1500 m thick) were accumulated during this period [Hsü et al., 1973]. It is believed that the Messinian Salinity Crisis (MSC) was not associated with a major climatic change before and after the crisis [Warny et al., 2003] even if more humid climatic condition are believed to have occurred locally during the MSC [Griffin, 2002; Gladstone et al., 2007]. A non-negligible climatic variability has been probably triggered by the astronomical forcing.

[3] The way in which the evaporites accumulated is still controversial. Meijer and Krijgsman [2005] calculated that a single Mediterranean sea-level lowering could explain $\sim 24-47 \mathrm{~m}$ of evaporite thickness. In consequence, more

\footnotetext{
${ }^{1}$ Institut Français du Pétrole, Rueil-Malmaison, France.

${ }^{2}$ Interactions et Dynamique des Environnements de Surface, University of Paris-Sud, Orsay, France.
}

Copyright 2008 by the American Geophysical Union. 0094-8276/08/2007GL032494 than one sea level draw down would be necessary to interpret the evaporite thickness. Blanc [2006] showed that a continuous inflow of water from the Atlantic during the MSC could explain a large quantity of evaporites. Nevertheless, a continuous sea water inflow is not easily compatible with the numerous Atlantic Ocean sea-level variations that occurred during the MSC [Miller et al., 2005] for a sill with a depth that range between $-50 \mathrm{~m}$ and $50 \mathrm{~m}$.

[4] To understand the MSC, it is of fundamental interest to analyse the role of the thresholds between the various sub-basins. The Rifian and Bethic Straits, located in the Gibraltar area, were the Mediterranean-Atlantic gateway. In the Sicily area another sill separates the Western and Eastern Mediterranean Basins (Figure 1). Here we discuss the role played by the threshold located between the Mediterranean Sea and the Gulf of Suez (GoS) (Figure 1). In the GoS, extension started about $23 \mathrm{Myr}$ ago. The extension was fast from 23 to $15 \mathrm{Ma}$ and decreased significantly until the Pliocene [Moretti and Colletta, 1987]. Several hundreds meters of evaporites were deposited between 10-15 Ma and $5 \mathrm{Ma}$ in the Belayim, South Gharib and Zeit formation [Bosworth et al., 2005; Schütz, 1994] (Figure 2a). The Zeit formation consists mainly of interbeds of anhydrite, shale and salt, and varies in thickness from some meters to $914 \mathrm{~m}$. The Zeit formation was deposited under alternating restricted and marine conditions to shallow marine setting [Alsharan and Salah, 1994]. Salt is also present southward in the Red Sea during this period. From Pliocene times, the rift trough narrowed and uplift affected the former coast and rift shoulders. Some evaporites were deposited locally during the Pliocene.

[5] The GoS is currently a branch of the Red Sea, disconnected from the Mediterranean Sea. However, it was connected to the Mediterranean prior to and during the MSC [Schütz, 1994]. Contemporaneously, the connection between the Red Sea and the Indian Ocean was not yet established [Bosworth et al., 2005]. The Red Sea was therefore dependent of the connection/disconnection that may have occurred with the Mediterranean through the GoS before and during the Messinian. In this study, we focus our attention on the evaporites accumulated in alternation with clastic material during the MSC. The role of the various parameters (sea level, oceanic inflow, river discharge, paleogeography) on the accumulation of evaporites is evaluated.

\section{Model and Method}

\subsection{Restoration of the Paleotopography}

[6] In order to improve our knowledge of the role of topography in controlling the deposition of evaporites, we restored the paleotopography in the GoS area. We first 


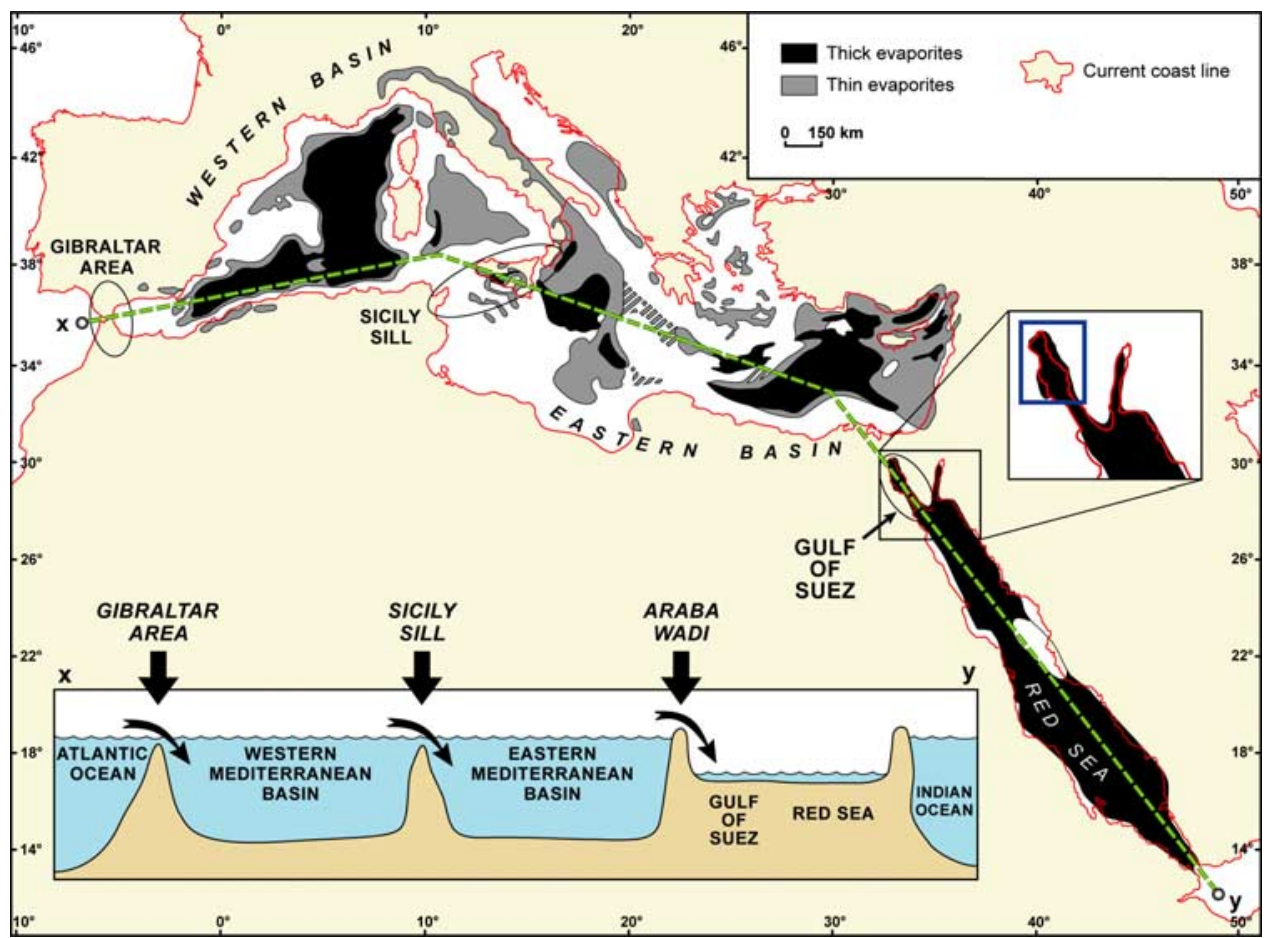

Figure 1. Mediterranean Basin map (modified from Montadert et al. [1978]) and schematic connection between the main Mediterranean basins during the Messinian.

constructed a map of the base of Middle Miocene evaporites (Figure 2b) as well as the top of the Messinian evaporites and of the Precambrian basement using seismic lines, DEM and geological maps from Colletta et al. [1988] and Moustafa et al. [2004]. We then reconstructed the paleogeography of the GoS as it was at the end of the Messinian. To restore the topography as it was at the end of the MSC, we assumed that the top of the evaporites was deposited horizontally. The restoration has been conducted using the software Gocad-Kine3D [Moretti et al., 2006]. The depth of the base of the evaporites, where post-Messinian deformation has been removed, is interpreted as the topography during the MSC. Our interpretation is based on the hypothesis that the deformation of the GoS was negligible between $10-15 \mathrm{Ma}$ and $5 \mathrm{Ma}$. The surface obtained (Figure 2c) has been used to calibrate the altitude of the threshold which

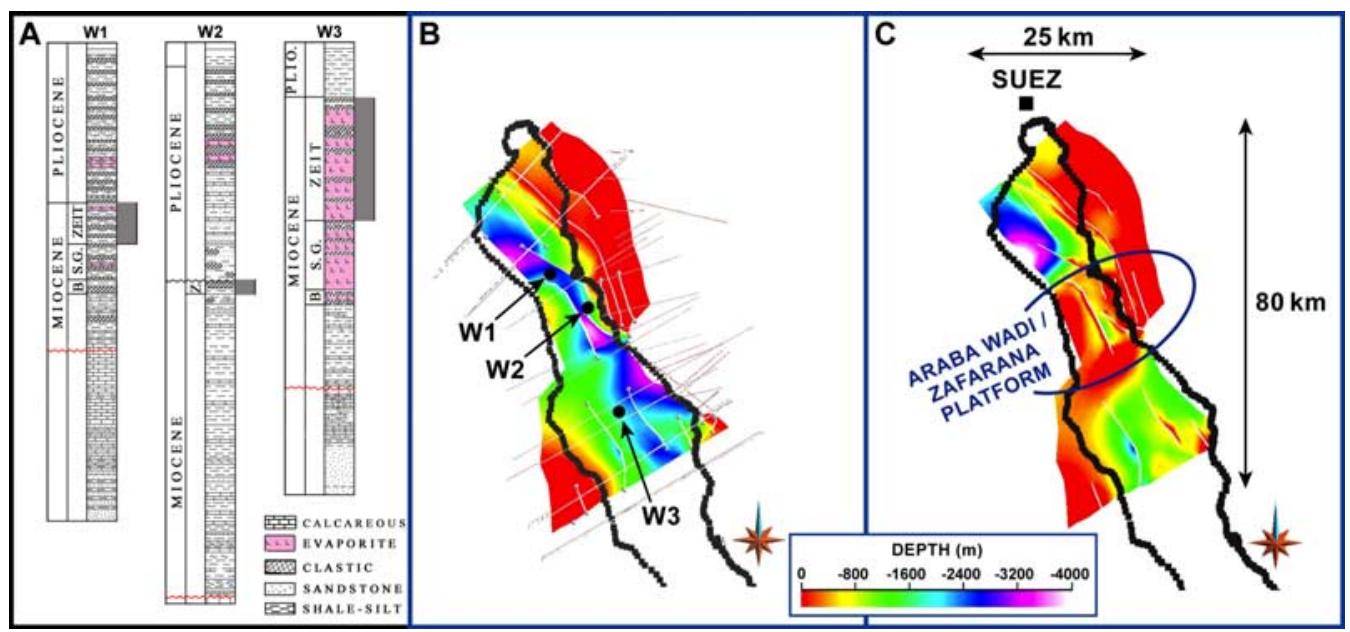

Figure 2. Northern part of the Gulf of Suez. See Figure 1 for location. The coast line is in black (a) Lithostratigraphic columns located around the Zafarana platform. Evaporites are in pink. The Zeit formation is considered to be of Messinian age. B, Belayim; SG, South Gharib. (b) Present base of evaporites constructed using interpreted seismic lines, geological map and DEM. (c) Base of evaporites restored at the end of the MSC. This map is interpreted as the topography in the GoS during the Messinian. 
separates the GoS from the Mediterranean Sea, in the model presented below.

\subsection{Modelling the Sea-Level Variation and the Salinity}

[7] The connection between the Mediterranean Basins and the Atlantic Ocean depends, on one hand, on openOcean sea level variation and, on the other hand, on the altitude of the various sills which connected the different sub-basins. We have also taken into account the role of river discharge, evaporation and precipitation. When a sub-basin is isolated, or has restricted sea water inflow, a water budget calculation can be performed.

[8] The water inflow is the sum of the rivers discharge $\mathrm{Q}_{\text {river }}$, of precipitation $\mathrm{P}$ and of the Atlantic Ocean flux Qocean (e.g. inflow-outflow). The fresh water loss is the consequence of the evaporation E. Starting from an initial volume Vo of the Mediterranean sub-Basin and considering the effect of evaporation, precipitation, sea water inflow and river discharge on the water budget, a new volume $\mathrm{V}(\mathrm{t})$ is calculated. When there is more outflow than water inflow, the water volume decreases and the sea level drops.

[9] The surface area $\mathrm{S}(\mathrm{t})$ is approximated from the volume variation $\Delta \mathrm{V}$ using the relation:

$$
\Delta \mathrm{V}=\mathrm{a} \cdot\left[\mathrm{S}^{2}(\mathrm{t}+\Delta \mathrm{t})-\mathrm{S}^{2}(\mathrm{t})\right] / 2
$$

where $\mathrm{t}$ is the time, $\Delta \mathrm{t}$ is the time step and a is a constant parameter. The sea level $\mathrm{Z}(\mathrm{t})$ is calculated from the surface area $\mathrm{S}(\mathrm{t})$ by the equation $\mathrm{Z}(\mathrm{t})=\mathrm{a} \cdot \mathrm{S}(\mathrm{t})+\mathrm{Z}_{0}$, where a and $\mathrm{Z}_{0}$ are constant parameters depending of the geometry of the sub-basins at the Messinian time [Blanc, 2006; Meijer and Krijgsman, 2005]. This method allows us to obtain a good approximation of the sea level variation of the Mediterranean Basin [Gargani and Rigollet, 2007]. For the Western Mediterranean Basin, a and $\mathrm{Z}_{0}$ are assumed to be equal to $4461.5 \cdot 10^{-12} \mathrm{~m}^{-1}$ and to $-3123 \mathrm{~m}$ respectively [Gargani and Rigollet, 2007]. These values allow to fit the geometry proposed by Meijer and Krijgsman [2005]. For the Eastern Mediterranean Basin, we assumed $\mathrm{a}=4461.5 \cdot 10^{-12} \mathrm{~m}^{-1}$ and $Z_{0}=-3581 \mathrm{~m}$. For the GoS, based on our basin reconstruction, the geometry of the basin is approximated by the coefficients $\mathrm{a}=1 \cdot 10^{-7} \mathrm{~m}^{-1}$ and $Z_{0}=-2500 \mathrm{~m}$.

[10] Assuming an initially uniform salinity of the Mediterranean $\mathrm{Co}=35 \mathrm{~g} / \mathrm{l}$, the simulated changes in water volume are used to calculate the variation of salinity. Furthermore, we considered that the salinity $\mathrm{C}_{\text {river }}$ of the river water is $\sim 1 \mathrm{~g} / \mathrm{l}$, whereas the salinity of the Atlantic Ocean sea water inflow $\mathrm{C}_{\text {ocean }}$ is assumed to have a constant value of $35 \mathrm{~g} / \mathrm{l}$. The salinity of the water evaporated is considered to be $0 \mathrm{~g} / \mathrm{l}$. In consequence, the salinity of the Mediterranean Basins at time $\mathrm{t}$ is:

$$
\mathrm{C}(\mathrm{t})=\left[\mathrm{Mo}+\mathrm{M}_{\text {river }}(\mathrm{t})+\mathrm{M}_{\text {ocean }}(\mathrm{t})\right] / \mathrm{V}(\mathrm{t})
$$

where $\mathrm{V}(\mathrm{t})$ is the volume of the sea water at the time $\mathrm{t}$ and $\mathrm{Mo}=\mathrm{Co} \cdot \mathrm{Vo}$ is the mass of evaporites minerals obtained if all the water in the Mediterranean evaporated (Co, initial sea water salinity; Vo, initial volume of the sea water), $\mathrm{M}_{\text {river }}(\mathrm{t})$ $=\mathrm{Q}_{\text {river }} \cdot \mathrm{C}_{\text {river }} \cdot \mathrm{t}$ is the mass of evaporites which come from river discharge $\mathrm{Q}_{\text {river }}, \mathrm{M}_{\text {ocean }}(\mathrm{t})=\mathrm{Q}_{\text {ocean }} \cdot \mathrm{C}_{\text {ocean }} \cdot \mathrm{t}$ is the mass of evaporites which come from the Atlantic Ocean through an oceanic inflow $\mathrm{Q}_{\text {ocean }}$ when the Mediterranean is only partly connected to the Atlantic Ocean.
[11] The sea-level in the Eastern Mediterranean Basin, as well as the altitude of the Zafarana threshold (Figure 2c), are necessary to calculate what occurred in the GoS. As a result, it is not possible to consider what happened in the GoS without considering what happened in the Western and Eastern Mediterranean Basins. We used here the results obtained by Gargani and Rigollet [2007] for the altitude of the sea-level in the Eastern Mediterranean Basin that take into account the role of astronomical forcing on climate variability.

\section{Results and Discussion}

\subsection{Evaporites in the Mediterranean Basins}

[12] The mass of evaporites accumulated is believed to be of $\mathrm{M}_{\text {West }}=1.44 \cdot 10^{18} \mathrm{~kg}$ in the Western Basin and of $\mathrm{M}_{\text {East }}$ $=6.44 \cdot 10^{18} \mathrm{~kg}$ in the Eastern Basin [Blanc, 2006]. This mass could be an overestimates. A volume $>106 \mathrm{~km}^{3}$, equivalent to $2.2 \cdot 10^{18} \mathrm{~kg}$, has been proposed by Ryan et al. [1973] for the whole basin. In the GoS, we estimated the mass of evaporites using the seismic lines published by Colletta et al. [1988] and Moustafa et al. [2004]. We obtained $0.4 \cdot 10^{16} \mathrm{~kg}<\mathrm{M}_{\text {Suez }}<1.4 \cdot 10^{16} \mathrm{~kg}$.

[13] There are at least three ways to accumulate the significant quantity of evaporites accumulated in the Mediterranean basins: (1) multiple sea level lowering events, (2) a semi-continuous sea water flux from the Atlantic (sea water salt concentration, $\mathrm{C}_{\text {Atlantic }}=35 \mathrm{~g} / \mathrm{l}$ ), and (3) the transport of a significant quantity of salt by rivers $\left(\mathrm{C}_{\text {river }} \sim 1\right.$ $\mathrm{g} / \mathrm{l})$.

[14] It is probable that more than one sea level lowering occurred during the MSC [Fortuin and Krijgsman, 2003]. We have calculated that more than 50 sea level draw down events are necessary to accumulate, by this process only, the entire Mediterranean evaporite deposit. Considering the hypothesis of 5 sea level lowering, as suggested by the 5 surface discontinuities observed in the Nile delta [Gargani and Rigollet, 2007], account for only $0.6510^{18} \mathrm{~kg}$ of the mass of evaporite.

[15] Even if the influence of river discharge on salinity is not negligible, the role of river water salinity in contributing to evaporite deposition in the Mediterranean is not always considered. When there is no connection between the Atlantic Ocean and the Mediterranean and under climatic conditions close to the present day, river discharge is not sufficient to explain alone the mass of evaporites. For example in the Western Basin, the salt concentration triggered by a river discharge of $7500 \mathrm{~m}^{3} / \mathrm{s}$ over $640 \mathrm{kyr}$ (from 5.96 to $5.32 \mathrm{kyr}$ [Krijgsman et al., 1999]) is less than $200 \mathrm{~g} /$ 1 (see auxiliary material). ${ }^{1}$ Nevertheless, there is an uncertainty in the climatic conditions (humid regionally [Griffin, 2002; Gladstone et al., 2007]/drier in the Northwest Mediterranean Basin and equal humid in the South of the Mediterranean [Fauquette et al., 2006] due also probably to climate variability associated with astronomical forcing. A very high river discharge associated with a significant evaporation rate could lead to a greater salinity of the sea water. This process cannot be excluded and may have played a significant role in the Evaporites Mass Accumulation (EMA).

\footnotetext{
${ }^{1}$ Auxiliary materials are available in the HTML. doi:10.1029/ 2007 GL032494.
} 

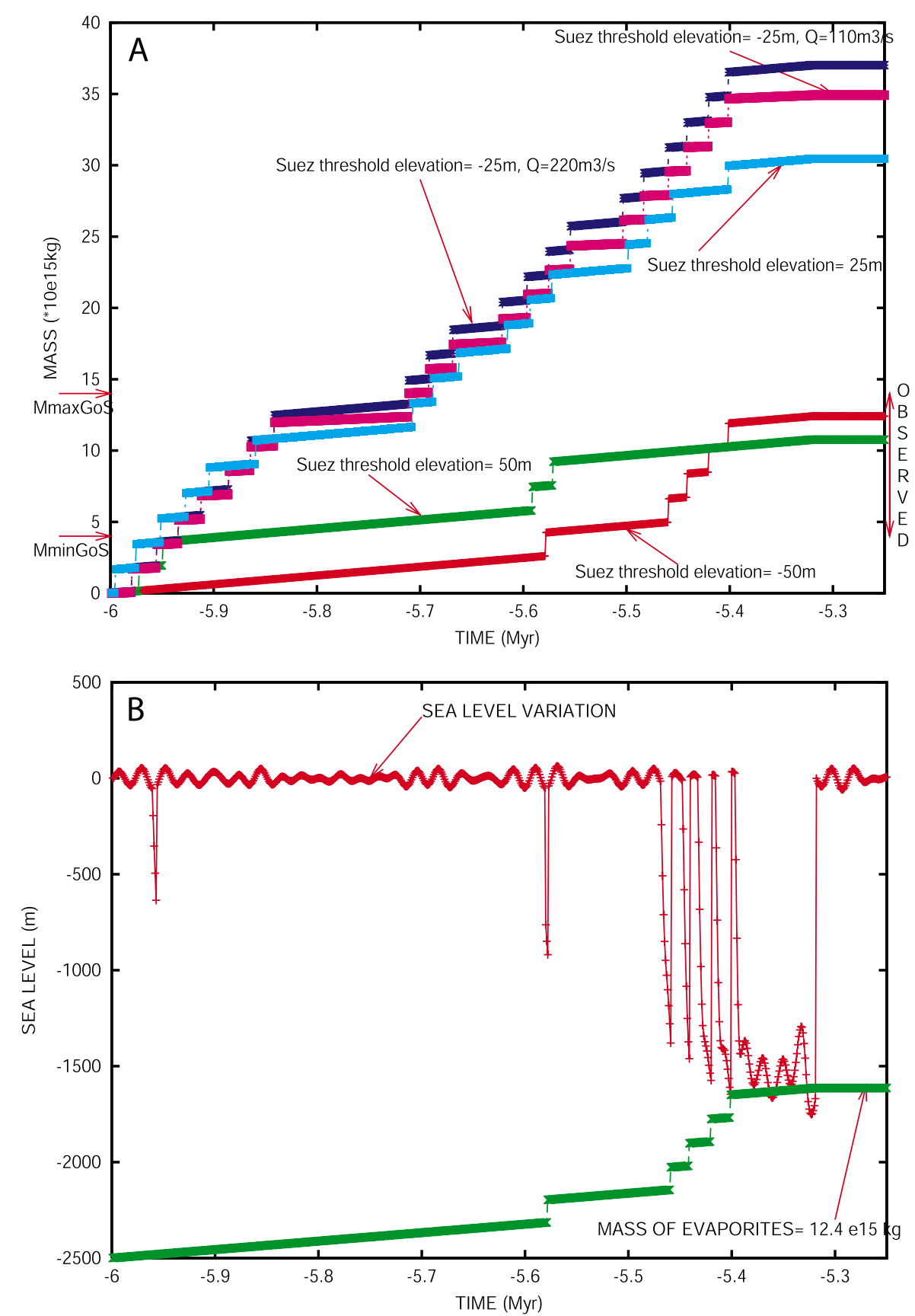

Figure 3. Effect of the MSC in the Suez of Gulf. (a) The Evaporite Mass Accumulation (EMA) is calculated for various elevations of the Suez threshold. When no indications are given the river discharge $Q_{\text {river }}$ is of $220 \mathrm{~m}^{3} / \mathrm{s}$, i.e. equivalent to a discharge produced by a mean precipitation rate of $0.5 \mathrm{~mm} /$ day $(0.2-1 \mathrm{~mm} /$ day [Gladstone et al., 2007]) on a drainage area of $250 \mathrm{~km} * 150 \mathrm{~km}$. The EMA is more sensitive to the paleogeographical threshold than to the river discharge. A threshold elevation of $-50 \mathrm{~m}$ or $+50 \mathrm{~m}$ could explain the mass of the evaporites accumulated during the MSC. (b) Sea level variation and EMA. The threshold between the Mediterranean Basin and the GoS has an elevation of $-50 \mathrm{~m}$. The EMA is triggered principally by the connection/disconnection between the Mediterranean Sea and the GoS, even if the climatic parameters also play a role. The salinity of the river discharge is $C_{\text {river }}=1 \mathrm{~g} / \mathrm{l}$. The value of E-P ranges between 0.5 and $0.9 \mathrm{~m} / \mathrm{year}$ [see Gargani and Rigollet, 2007].

[16] There is another process that could have played a role in controlling salinity during the Messinian. Oceanic inflow may explain the mass of evaporites. For example, sea water inflow from the Atlantic of $\sim 11000 \mathrm{~m}^{3} / \mathrm{yr}$, occurring over $\sim 29 \mathrm{kyr}$ (see auxiliary material) may explain a significant part of the evaporites mass in the Western Basin
$\left(\mathrm{M}=\mathrm{C}(\mathrm{t}) \cdot \mathrm{V}(\mathrm{t}) \sim 0.5 \cdot 10^{18} \mathrm{~kg}\right)$ and allows us to interpret the intermediate lowstand of $\sim-500 \mathrm{~m}$ observed in the Western Mediterranean Basin [Gargani, 2004]. As the intermediate lowstand of $\sim-500 \mathrm{~m}$ is also compatible with numerous sea level lowering events of short duration [Gargani and Rigollet, 2007], it is not clear whether 
continuous or semi-continuous Atlantic sea water inflow occurred.

[17] A combination of these three processes (i.e. several sea level lowering events, significant river discharge, a continuous or semi-continuous Atlantic sea water inflow) permits to interpret the mass of evaporites accumulated.

\subsection{The Gulf of Suez (GoS) Case}

[18] It is now possible to discuss the development of the salt basin within the GoS during the Messinian. Our results presented Figure 2c show that the northern current depot centre could have been isolated from the South. A threshold existed. The Zeit formation thickness is indeed very small in the well 2 located in this area (Figure 2a). Our results suggest that the Araba Wadi/Zafarana structure corresponds to this threshold and had an altitude of $-50 \mathrm{~m}<\mathrm{Z}<50 \mathrm{~m}$ during the MSC (Figure 2c). This structure is known to have played a role in blocking the southern part of the GoS from the Eastern Mediterranean during the Middle and Late Miocene [Schütz, 1994]. It is coincident with a pre-existing structure of presumed Precambrian age [Polis et al., 2005] and was a topographic high as far back as the latest Maastrichtian [Scheibner et al., 2001]. The restoration of the topography shows that the southern GoS and the Red Sea may have been isolated by the Zafarana platform from the Mediterranean during the Miocene. Evaporation and salt deposition have taken place since the Red Sea was isolated southward from the Indian Ocean. One may note that due to local structuring, very small isolated basin may have formed in the half graben of the tilted block, as it happens today, leading also to small local evaporitic deposition.

[19] Our quantitative model of the water and salinity budget shows that the sea water variations in the GoS were highly influenced by the elevation of the Zafarana structure. Several draw down events in the Suez sub-Basin occurred as a consequence of this threshold which isolated the GoS/ Red Sea from the Mediterranean (Figure 3b) and the conditions of sedimentation were strongly influenced. The simulated mass of evaporites $\left(1 . \cdot 10^{16} \mathrm{~kg}<\mathrm{M}<3.7 \cdot 10^{16}\right.$ $\mathrm{kg}$; Figure $3 \mathrm{a}$ ), calculated using the whole range of possible values for the elevation of the threshold $(-50 \mathrm{~m}<\mathrm{z}<+50$ $\mathrm{m})$, allows us to interpret the estimates of the evaporite mass from seismic lines $\left(0.4 \cdot 10^{16} \mathrm{~kg}<\mathrm{M}_{\text {Suez }}<1.4 \cdot 10^{16} \mathrm{~kg}\right)$. In the case of the GoS, it is not necessary to consider a continuous sea water inflow from the Mediterranean to explain the evaporite mass. The model suggests that the elevation of the Suez threshold was $\sim-50 \mathrm{~m}$ or $\sim+50 \mathrm{~m}$. Intermediate values of the elevation of the Suez threshold $(-25 \mathrm{~m}<$ threshold $<+25 \mathrm{~m})$ produced too much evaporite mass accumulation (Figure $3 \mathrm{a}$ ). The intercalation of 300 to $900 \mathrm{~m}$ of Messinian evaporites, sandstones and clays in the GoS [Schütz, 1994; Griffin, 2002] could be interpreted by our modelling as an alternation of connection/disconnection from the Mediterranean Sea (Figures 2a and 3b). The existence of the Zafarana threshold before and probably after the MSC explain why evaporites are also observed before and after the MSC.

[20] The nature of the Messinian climate is controversial [Fauquette et al., 2006; Gladstone et al., 2007]. Gladstone et al. [2007] estimated that the precipitation rate ranges between 0.2 and $1 \mathrm{~mm} /$ day during the Messinian in the GoS area, whereas evaporation rate range between 0.8 and $1 \mathrm{~mm} /$ day. Furthermore, a climatic variability due to the astronomical forcing should also be considered. We have tested the effect of a precipitation rate of $0.5 \mathrm{~mm}$ /day in a drainage area of $250 \mathrm{~km} * 150 \mathrm{~km}$ (i.e. $\sim 220 \mathrm{~m}^{3} / \mathrm{s}$ for the GoS). The value of the hydrological parameters (Evaporation-precipitation, rivers discharge) influence moderately the accumulation of the mass of evaporite in the GoS in comparison of the role of the Zafarana threshold (Figure 3a: see comparison between a river discharge of $\sim 220 \mathrm{~m}^{3} / \mathrm{s}$ and of $\sim 110$ $\mathrm{m}^{3} / \mathrm{s}$ ). In consequence, our approximation of the hydrological parameters allows us to obtain a first order understanding of the sedimentological evolution of the GoS during the MSC and of the elevation of the threshold of the Zafarana platform.

\section{Conclusions}

[21] We have reconstructed the paleogeography of the threshold between the Mediterranean and the Gulf of Suez during the Messinian (Figure 2b). This threshold, which has an elevation of $\sim-50 \mathrm{~m}$ or $\sim+50 \mathrm{~m}$, strongly influenced the sea water connection between the Mediterranean and the GoS (Figure 3). The role played by this threshold is more significant than the role played by the river discharge on the accumulation of evaporite in the GoS (Figure 3a).

[22] In the Western Mediterranean Basin, a semi-continuous inflow of sea water from the Atlantic could explain part of the large quantity of evaporites. Another non negligible part is a consequence of the sea level lowering and the river discharge into the Western and Eastern Mediterranean Basins. Inflow from the Atlantic may also explain the existence of an intermediate lowstand $(\sim-500$ $\mathrm{m})$.

[23] We believe that this approach could be useful for explaining part water budgets and the impact of climatic conditions (dry/wet; cold/hot) on isolated basins.

[24] Acknowledgments. We would like to thanks Julien Schmitz and Denis Deldique for their help with DEM and figure artwork, as well as Rachel Flecker and an anonymous reviewer for their constructive comments.

\section{References}

Alsharan, A. S., and M. G. Salah (1994), Geology and hydrocarbon habitat in a rift setting: southern Gulf of Suez, Egypt, Bull. Can. Pet. Geol., 42(3), 312-331.

Blanc, P.-L. (2006), Improved modelling of the Messinian Salinity Crisis and conceptual implications, Palaeogeogr. Palaeoclimatol. Palaeoecol., 238(1-4), 349-372.

Bosworth, W., P. Huchon, and K. McClay (2005), The Red Sea and Gulf of Aden Basins, J. Afr. Earth Sci., 43, 334-378.

Colletta, B., P. Le Quellec, J. Letouzey, and I. Moretti (1988), Longitudinal evolution of the Suez rift structure (Egypt), Tectonophysics, 153, 221233.

Fauquette, S., et al. (2006), How much did climate force the Messinian salinity crisis? Quantified climatic conditions from pollen records in the Mediterranean region, Palaeogeogr. Palaeoclimatol. Palaeoecol., $238(1-4), 281-301$.

Fortuin, A. R., and W. Krijgsman (2003), The Messinian of the Nijar Basin (SE Spain): Sedimentation, depositional environments and paleogeographic evolution, Sediment. Geol., 160, 213-242.

Gargani, J. (2004), Modelling of the erosion in the Rhone valley during the Messinian crisis (France), Quat. Int., 121, 13-22.

Gargani, J., and C. Rigollet (2007), Mediterranean Sea Level variations during the Messinian Salinity Crisis, Geophys. Res. Lett., 34, L10405, doi:10.1029/2007GL029885.

Gladstone, R., R. Flecker, P. Valdes, D. Lunt, and P. Marwick (2007), The Mediterranean hydrologic budget from a Late Miocene global climate simulation, Palaeogeogr. Palaeoclimatol. Palaeoecol., 251, 254-267. 
Griffin, D. L. (2002), Aridity and humidity: two aspects of the late Miocene climate of North Africa and the Mediterranean, Palaeogeogr. Palaeoclimatol. Palaeoecol., 182, 65-91.

Hsü, K. J., W. B. F. Ryan, and M. B. Cita (1973), Late Miocene desiccation of the Mediterranean, Nature, 242, 240-244.

Krijgsman, W., F. J. Hilgen, I. Raffi, F. J. Sierro, and D. S. Wilson (1999), Chronology, causes and progression of the Messinian salinity crisis, Nature, 400, 652-655.

Meijer, P. T., and W. A. Krijgsman (2005), Quantitative analysis of the desiccation and re-filling of the Mediterranean during the Messinian Salinity Crisis, Earth Planet. Sci. Lett., 240, 510-520.

Miller, K. G., et al. (2005), The Phanerozoic record of global sea-leve change, Science, 310, 1293-1298.

Montadert, L., J. Letouzey, and A. Mauffret (1978), Messinian event: Seismic evidence, Initial Rep. Deep See Drill. Proj., Part 1, 42, 1037-1050, doi:10.2973/dsdp.proc.42-1.154

Moretti, I., and B. Colletta (1987), Spatial and temporal evolution of the Suez rift subsidence, Geodynamics, 7, 151-168

Moretti, I., F. Lepage, and M. Guiton (2006), KINE3D: A new 3D restoration method based on a mixed approach linking geometry and geomechanics, Oil Gas Sci. Technol., 61(2), 277-289.

Moustafa, A. R., et al. (2004), Geological maps and section of the Sinai margin, AAPG/Datapages GIS Series, Am. Assoc. of Pet. Geol., Tulsa, Okla.
Patton, T. L., A. R. Moustafa, and R. A. Nelson (1994), Tectonic Evolution and structural Setting of the Suez Rift, in Interior Rift Basins, edited by S. M. Landon, AAPG Mem., 59, 9-55.

Polis, S. R., M. T. Angelich, C. R. Beeman, W. B. Maze, D. J. Reynolds, D. M. Steinhauff, A. Tudoran, and M. Wood (2005), Preferential deposition and preservation of structurally-controlled synrift reservoirs: Northeast Red Sea and Gulf of Suez, Geoarabia, 10(1), 97-122.

Ryan, W. B. F., et al. (1973), Initial Reports of the Deep Sea Drilling Project, vol. 13, 1447 pp., U.S. Govt. Print. Off., Washington, D. C.

Scheibner, C., A. M. Marzouk, and J. Kuss (2001), Maastrichtian-Early Eocene litho-biostratigraphy and paleogeography of the northern Gulf of Suez region, Egypt, J. Afr. Earth Sci., 32(2), 223-255.

Schütz, K. I. (1994), Structure and stratigraphy of the Gulf of Suez, Egypt, in Interior Rift Basins, edited by S. M. Landon, AAPG Mem., 59, 57-96.

Warny, S. A., P. J. Bart, and J.-P. Suc (2003), Timing and progression of climatic, tectonic and glacioeustatic influences on the Messinian Salinity Crisis, Palaeogeogr. Palaeoclimatol. Palaeoecol., 202, 59-66.

J. Gargani, Interactions et Dynamique des Environnements de Surface, University of Paris-Sud, F-91405 Orsay, France. (julien.gargani@u-psud.fr) J. Letouzey and I. Moretti, IFP, BP 311, F-92852 Rueil-Malmaison Cedex, France. 